\title{
Las pasantías como recurso didáctico de articulación entre escuela media-universidad
}

\author{
Medina, Marcela F. ${ }^{1}$; Torres, Cristina; Romero, Cintia; González, María E.
}

\section{Resumen}

Este trabajo relata la experiencia de alumnos del último año de la educación secundaria que realizaron pasantías en la Facultad de Bioquímica, Química y Farmacia de la UNT. Las pasantías son un recurso didáctico de enseñanza y de aprendizaje de la Biología para facilitar la articulación entre los niveles educativos Escuela Media-Universidad. Las actividades desarrolladas en las pasantías propiciaron en los alumnos la construcción de aprendizajes significativos para iniciarlos en la práctica de la investigación científica en laboratorios de la Universidad. La evaluación de esta estrategia se efectuó sobre la base de: a-el interés y la respuesta de los jóvenes ante las exigencias académicas, b-la autonomía en la elaboración y organización de los conocimientos adquiridos y c-la capacidad para transferir a sus pares lo aprendido. Los resultados obtenidos proporcionaron a los estudiantes experiencias de enseñanza, de aprendizaje y de evaluaciones valiosas y trascendentes. El informe final con el que cada grupo culminó su proyecto constituyó una síntesis integradora de los saberes teóricos y prácticos. Puede afirmarse que: -El recurso didáctico utilizado fue significativo y alentador. -Las pasantías educativas empleadas posibilitaron que los docentes del nivel medio realizaran revisiones y ajustes sobre las temáticas específicas para facilitar el tránsito académico de los alumnos en el nivel superior.

Palabras Clave: articulación, nivel medio-universidad, innovación, pasantías, biología

\footnotetext{
${ }^{1}$ Facultad de Bioquímica, Química y Farmacia. Universidad Nacional de Tucumán. Argentina. Chacabuco 461 (4000) Tucumán Argentina. Argentina. Fax: 54-381-4248025

mmedina@fbqf.unt.edu.ar; mafamedina@gmail.com
} 


\section{SUMMARY}

Internships as a didactic tool inhigh school/university articulation

This work reports the experience of students in the final year of high school who were interns in the Faculty of Biochemistry, Chemistry and Pharmacy of the National University of Tucumán. Internships are a didactic tool in the teaching and learning of Biology in order to make easier the articulation between high school and college. The activities undertaken in the internships encouraged students to construct significant learning to start them in the practice of scientific investigation in university labs. The assessment of this strategy was carried out on the basis of: a- interest and response of the students involved in the process to academic requirements, $b$ - the interns' autonomy in the elaboration and organization of the knowledge acquired, and c-their ability to transmit their new knowledge to their peers. The results obtained gave students teaching, learning and evaluation experiences that were valuable and lasting. The final report with which each student group completed its Project was a synthesis integrating theoretical and practical knowledge. It can be concluded that: -The didactic tool used was significant and encouraging. - Internships enabled high school teachers to revise and adjust specific subjects in order to facilitate the transition from high school to university.

Keywords: articulation, high school-university, innovation, internships, Biology 